\title{
The Effect of 12-Week Regular Pilates, Step and Zumba Training Program on Muscle and Fat Weight
}

\author{
Mehmet İmamoğlu ${ }^{1}$, Serhat Özdenk ${ }^{1}$ \\ ${ }^{1}$ Department of Sport Management, Faculty of Sport Sciences, Sinop University, Sinop, Turkey \\ Correspondence: Mehmet İMAMOĞLU, Department of Sport Management, Faculty of Sport Sciences, Sinop \\ University, Sinop, Turkey.
}

Received: August 1, 2019

Accepted: August 18, 2019

Online Published: August 22, 2019

doi:10.11114/jets.v7i11.4421

URL: https://doi.org/10.11114/jets.v7i11.4421

\begin{abstract}
This study aimed to investigate the effect of Pilates, Step and Zumba exercises on muscle and fat weight in arms, legs, core abdominal area, and total body.

A total of 60 women aged 19 to 62 participated in the study. The mean age was $45 \pm 10$ years, height was $160 \pm 5 \mathrm{~cm}$ and weight was $72.31 \pm 11.12 \mathrm{~kg}$. Pilates, Step and Zumba exercise program was applied three days a week for a total of 12 weeks. Regional and total muscle and fat weights in the body were analyzed by TANITA MC780. Statistical significance level was determined as $\mathrm{p}<0.05$. In the Pilates exercises group, there was a statistically significant difference between the pre-posttest muscle weights of the arms, core abdominal area and total body $(\mathrm{p}<0.05)$ except legs $(\mathrm{p}>0.05)$. There was no statistically significant difference between pre-posttest muscle weights in arms, legs, core abdominal area and total body in Step and Zumba exercises group ( $p>0.05)$. In Pilates and Step exercise groups, there is a statistically significant difference between pre-posttest fat weights in arms, legs, core abdominal area and total body $(p<0.05)$ except Zumba groups ( $p>0.05)$. Pilates, Step and Zumba exercises groups were evaluated among themselves, there was no difference in terms of the arm, leg, core abdominal area, and total body muscle weights both in the pre-post tests ( $>0.05)$. There was a statistically significant difference between all groups in terms of the arm, leg, core abdominal area and total body fat weights in both pre-posttests $(\mathrm{p}<0.05)$.

Pilates and Step exercises can be recommended to women who want to reduce their weight on arms, legs, core abdominal area and total body fat lose weight.
\end{abstract}

Keywords: fitness, physical education, sport exercises

\section{Introduction}

The Pilates method and related exercises were developed by Joseph Pilates in the 1920s. This method is based on the principles of centering, concentration, control, breath, precision, and fluidity (Latey, 2001). High levels of concentration, control of the body, proper breathing, and full and fluent movements are essential for Pilates exercises. Although there are not enough studies to show that Pilates exercises improve women's health but Pilates method has gained popularity in terms of physical and therapeutic improvement (Mazzarino, Kerr, Wajswelner, \& Morris, 2015). The positive effects of Pilates exercise on body composition have been determined in researches (García and Lain, 2011; Singh and Singh, 2014). Pilates exercises, which are performed only once a week for individuals with a sedentary lifestyle, can encourage the transition to a healthy and active lifestyle (Tolnai, Szabó, Köteles, \& Szabo, 2016).

The Step exercises are being performed with the help of a platform high above the ground. The movements are carried out in all directions, on top of the platform, besides, behind and in front. The movements during the exercise are performed with music and rhythmically.

Zumba is a dance exercise practiced by millions of people around the world and has many potential benefits in research (Delextrat, Warner, Graham, \& Neupert, 2016). Zumba is defined as a Latin-inspired dance exercise program, which is usually implemented in large groups of participants, combining Latin rhythms and aerobic Steps, creating a kind of choreography that includes all body movements and is less formal than other group exercises (Luettgen, Foster, Doberstein, Mikat, \& Porcari, 2012). It can be said that Zumba exercises increase flexibility and body resistance and help to fight stress and improve mood. Zumba is promoted by the fitness industries as an intensive cardiovascular exercise to help people lose weight. 
The smooth functioning of the cardiovascular system is the key to a healthy life. Any problem in the cardiovascular system poses many risks. It can cause many health problems such as high blood pressure, vascular blockages and stroke. Among the reasons for the emergence of cardiovascular diseases; malnutrition, obesity, stress, and sedentary lifestyles. Regular aerobic exercise (especially aerobic dance exercises by women) positively affects the cardiovascular system and helps to control weight (Garrick \& Requa, 1988). Similar to those participating in aerobic dance programs and other endurance exercises, there is an improvement in their cardiovascular system (Williford, Scharff-Olson, \& Blessing, 1989).

Obesity is an important risk factor for the emergence of health problems, so many countries are looking for ways to reduce body fat in individuals to prepare obesity prevention programs (Manson, et al., 1990; Terry, Stefanick, Haskell, $\&$ Wood, 1991). Prevention programs for obesity include increasing physical activity and reducing calories (Jakicic, et al., 2001). Future health risks can be determined from body fat measurements, for example, excessive body fat causes health problems, and so there is increasing interest in body composition measurements in which variables such as body fat are identified (Jebb, Cole, Doman, Murgatroyd, \& Prentice, 2000). Physical activities contribute to the improvement of body composition in the control of variables such as exercise duration and diet (Scharff-Olson, Williford, Blessing, \& Brown, 1996).

Nowadays, Pilates, Zumba exercises are very popular among women in terms of weight loss and body tightening (Baştuğ, Özcan, Gültekin, \& Günay, 2016). Therefore, this study is important. In this study aims to investigate the effect of Pilates, Step and Zumba exercises on muscle and fat weight in arms, legs, core abdominal area, and total body.

\section{Method}

This study is an experimental study that deals with the changes in arms, legs, core abdominal area, and total body muscle and fat weights of women who participate in Pilates, Step and Zumba exercises voluntarily.

\subsection{Sample of Participants}

There is no criterion for participation in the study. The age, height and weight values of the women participating in the exercises according to Pilates, Step and Zumba groups are shown in table 1.

Table 1. Age, height, and weight values

\begin{tabular}{lllllllllll}
\hline & & \multicolumn{3}{l}{ Age (year) } & \multicolumn{3}{c}{ Height $(\mathrm{cm})$} \\
\cline { 3 - 10 } & $\mathrm{N}$ & Mean \pm Std. & Min. & Max. & Mean \pm Std. & Min. & Max. & Mean \pm Std. & Min. & Max. \\
\hline Pilates & 39 & $48 \pm 9$ & 24 & 62 & $159 \pm 5$ & 150 & 172 & $74.66 \pm 11.40$ & 56.90 & 101.50 \\
Step & 10 & $39 \pm 10$ & 23 & 51 & $160 \pm 3$ & 154 & 164 & $67.43 \pm 10.21$ & 57.40 & 92.40 \\
Zumba & 11 & $37 \pm 10$ & 19 & 50 & $162 \pm 6$ & 150 & 171 & $68.43 \pm 9.00$ & 54.10 & 82.50 \\
Total & 60 & $45 \pm 10$ & 19 & 62 & $160 \pm 5$ & 150 & 172 & $72.31 \pm 11.12$ & 54.10 & 101.50 \\
\hline
\end{tabular}

A total of 60 women; ages are in the range of 19-62 year and the average is $45 \pm 10$ years, heights are in the range of $150-172 \mathrm{~cm}$ and the average is $160 \pm 5 \mathrm{~cm}$, weights are in the range of $54.10-101.50 \mathrm{~kg}$ and the average is $72.31 \pm 11.12$ $\mathrm{kg}$.

\subsection{Body Analysis Measurements}

Regional and total muscle and fat weights in the body were analyzed. Regional data were obtained from the arms, legs and core abdominal area. Muscle and fat mass refer to the actual weight of muscle and fat in our body. Body analysis measurements in this study were performed with Tanita MC780. Tanita body fat analyzer was developed to estimate body fat based on the principle of bioelectrical impedance analysis (Nunez, et al., 1997). When you stand on a Tanita monitor, the data obtained by sending a very low, safe electrical signal from the four metal electrodes to your legs and abdomen than data entered into the Tanita equations and the body composition measurements are calculated in under 20 seconds ("Professional Scales", 2019). The measurements were made to ensure that the feet were dry and bare. The measurements were expected to take an average of three hours after sport, meal or sleep.

\subsection{Exercise Program}

There is strong evidence of both physical and psychological health benefits of low frequency (once a week) and short-term (6-10 weeks) Pilates training programs (Tolnai, Szabó, Köteles, \& Szabo, 2016).

Pilates, Step and Zumba exercise programs were applied three days a week for a total of 12 weeks. Three days of Pilates exercise program includes aerobics for two days and fitness exercises for one day. It includes 40 minutes of floor exercises at a low tempo, two minutes of rest and 20 minutes of aerobic movements. The Step program includes two-step and one-day fitness exercises. 20 minutes' aerobics, 20 minutes' step, and 30 minutes' cushion movements. 
There are three minutes of rest between aerobic movements and two minutes when moving from step to floor exercises. The Zumba exercise program, which is applied for three days, includes two days of Zumba and one day of fitness exercises. Movements that last for 10-13 songs take about 55 minutes. After each song, a break of 20 seconds is given. The program is completed with cool down exercises 10 minutes.

\subsection{Statistics and Data Analysis}

IBM SPSS 21 software was used in the calculation and evaluation of the data, the statistical significance level was determined as $\mathrm{p}<0.05$, normality level was evaluated by Kolmogorov-Smirnov and variance equation by Levene test. Mean, standard deviation, minimum and maximum values were taken into consideration in the analysis of body analysis data. Paired Sample t test was used to compare the pre-post tests measurements for pilates, step and zumba in terms of body analysis values. One-way ANOVA was used to test the difference between the groups during the pre-posttests. Post-hoc LSD and Tamhane tests were used to determine the source of the difference between the groups.

\section{Results}

The relationship between the pre-post tests weight of muscle values according to Pilates, Step and Zumba groups is shown in table 2.

Table 2. The relationship between the pre-post tests weight of muscle values

\begin{tabular}{|c|c|c|c|c|c|c|c|c|c|c|c|c|}
\hline \multirow{3}{*}{$\begin{array}{l}\text { Weights of } \\
\text { muscle }\end{array}$} & \multicolumn{4}{|c|}{ Pilates $(\mathrm{N}=39)$} & \multicolumn{4}{|c|}{ Step $(N=10)$} & \multicolumn{4}{|c|}{ Zumba $(\mathrm{N}=11)$} \\
\hline & Pre & Post & & & Pre & Post & & & Pre & Post & & \\
\hline & $\mathrm{X} \pm$ Std. & $\mathrm{X} \pm$ Std. & $\mathrm{t}$ & $\mathrm{p}$ & $\mathrm{X} \pm$ Std. & $\mathrm{X} \pm$ Std. & $\mathrm{t}$ & $\mathrm{p}$ & $\mathrm{X} \pm$ Std. & $\mathrm{X} \pm$ Std. & $\mathrm{t}$ & $\mathrm{p}$ \\
\hline Arms (kg) & $\begin{array}{l}4.7 \\
\pm 0.54\end{array}$ & $\begin{array}{l}4.82 \\
\pm 0.56\end{array}$ & -3.909 & $.000 *$ & $\begin{array}{l}4.33 \\
\pm 0.5\end{array}$ & $\begin{array}{l}4.43 \\
\pm 0.39\end{array}$ & -1.861 & .096 & $\begin{array}{l}4.5 \\
\pm 0.67\end{array}$ & $\begin{array}{l}4.52 \\
\pm 0.68\end{array}$ & -.582 & .574 \\
\hline Legs (kg) & $\begin{array}{l}14.36 \\
\pm 1.46\end{array}$ & $\begin{array}{l}14.45 \\
\pm 1.36\end{array}$ & -.944 & .351 & $\begin{array}{l}13.76 \\
\pm 1.27\end{array}$ & $\begin{array}{l}14.04 \\
\pm 1.1\end{array}$ & -.504 & .626 & $\begin{array}{l}14.4 \\
\pm 1.04\end{array}$ & $\begin{array}{l}14.2 \\
\pm 1.1\end{array}$ & 2.057 & .067 \\
\hline $\begin{array}{l}\text { Core abdominal } \\
\text { area }(\mathrm{kg})\end{array}$ & $\begin{array}{l}26.91 \\
\pm 2.92\end{array}$ & $\begin{array}{l}27.53 \\
\pm 3.03\end{array}$ & -4.222 & $.000 *$ & $\begin{array}{l}25.99 \\
\pm 2.4\end{array}$ & $\begin{array}{l}26.28 \\
\pm 2.01\end{array}$ & -1.134 & .286 & $\begin{array}{l}26.49 \\
\pm 2.86\end{array}$ & $\begin{array}{l}26.53 \\
\pm 2.86\end{array}$ & -.197 & .848 \\
\hline Total body (kg) & $\begin{array}{l}45.98 \\
\pm 4.82\end{array}$ & $\begin{array}{l}46.8 \\
\pm 4.86\end{array}$ & -3.341 & $.002 *$ & $\begin{array}{l}44.66 \\
\pm 4.2\end{array}$ & $\begin{array}{l}44.75 \\
\pm 3.41\end{array}$ & -.222 & .829 & $\begin{array}{l}45.39 \\
\pm 4.5\end{array}$ & $\begin{array}{l}45.26 \\
\pm 4.55\end{array}$ & .374 & .716 \\
\hline
\end{tabular}

$* \mathrm{p}<0.05$

There was a statistically significant difference between the pre-posttest measurements of the arms, core abdominal area and total body muscle weight of women who participated in Pilates exercises $(p<0.05)$, whereas there was no statistically significant difference between legs muscle weights pre-posttests measurements ( $>0.05)$. There was no statistically significant difference between the pre-post tests measurements of arms, legs, core abdominal area and total body muscle weights of women who participated in Step and Zumba exercises ( $p>0.05$ ).

The relationship between the pre-post tests weight of fat values according to Pilates, Step and Zumba groups is shown in table 3.

Table 3. The relationship between the pre-post tests weight of fat values

\begin{tabular}{|c|c|c|c|c|c|c|c|c|c|c|c|c|}
\hline \multirow{3}{*}{$\begin{array}{l}\text { Weights of } \\
\text { fat }\end{array}$} & \multicolumn{4}{|c|}{ Pilates $(\mathrm{N}=39)$} & \multicolumn{4}{|c|}{ Step $(N=10)$} & \multicolumn{4}{|c|}{ Zumba $(\mathrm{N}=11)$} \\
\hline & Pre & Post & & & Pre & Post & & & Pre & Post & & \\
\hline & $\mathrm{X} \pm$ Std. & $\mathrm{X} \pm$ Std. & $\mathrm{t}$ & $\mathrm{p}$ & $\mathrm{X} \pm$ Std. & $\mathrm{X} \pm$ Std. & $\mathrm{t}$ & $\mathrm{p}$ & $\mathrm{X} \pm$ Std. & $\mathrm{X} \pm$ Std. & $\mathrm{t}$ & $\mathrm{p}$ \\
\hline Arms (kg) & $\begin{array}{l}3,21 \\
\pm 1,38\end{array}$ & $\begin{array}{l}3,05 \\
\pm 1,37\end{array}$ & 2,767 &, $009^{*}$ & $\begin{array}{l}2,42 \\
\pm 1,04\end{array}$ & $\begin{array}{l}1,96 \\
\pm 0,87\end{array}$ & 7,233 &, $000 *$ & $\begin{array}{l}2,33 \\
\pm 0,61\end{array}$ & $\begin{array}{l}2,25 \\
\pm 0,57\end{array}$ & 1,330 & ,213 \\
\hline Legs (kg) & $\begin{array}{l}11,6 \\
\pm 2,92\end{array}$ & $\begin{array}{l}11,32 \\
\pm 2,98\end{array}$ & 2,532 &, $016^{*}$ & $\begin{array}{l}9,2 \\
\pm 2,32\end{array}$ & $\begin{array}{l}8,48 \\
\pm 2\end{array}$ & 5,476 &, $000 *$ & $\begin{array}{l}9,31 \\
\pm 1,89\end{array}$ & $\begin{array}{l}9,37 \\
\pm 1,75\end{array}$ &,- 308 & ,764 \\
\hline $\begin{array}{l}\text { Core abdominal } \\
\text { area }(\mathrm{kg})\end{array}$ & $\begin{array}{l}11,38 \\
\pm 3,29\end{array}$ & $\begin{array}{l}10,25 \\
\pm 3,69\end{array}$ & 4,625 &, $000 *$ & $\begin{array}{l}8,74 \\
\pm 3,33\end{array}$ & $\begin{array}{l}7,05 \\
\pm 3,19\end{array}$ & 8,215 &, $000 *$ & $\begin{array}{l}8,95 \\
\pm 3,13\end{array}$ & $\begin{array}{l}8,73 \\
\pm 3,13\end{array}$ &, 740 & ,476 \\
\hline Total body (kg) & $\begin{array}{l}26,21 \\
\pm 7,25\end{array}$ & $\begin{array}{r}24,63 \\
\pm 7,46 \\
\end{array}$ & 4,177 &, $000 *$ & $\begin{array}{l}20,36 \\
\pm 6,61\end{array}$ & $\begin{array}{l}17,49 \\
\pm 6\end{array}$ & 8,760 &, $000 *$ & $\begin{array}{l}20,6 \\
\pm 5,44\end{array}$ & $\begin{array}{l}20,36 \\
\pm 5,16\end{array}$ & ,490 & ,635 \\
\hline
\end{tabular}

$* \mathrm{p}<0.05$

There was a statistically significant difference between the pre-posttest measurements of the arms, legs, core abdominal area and total body fat weights of the women who participated in Pilates and Step exercises ( $<<0.05)$. There was no statistically significant difference between the pre-posttest measurements of arms, legs, core abdominal area and total body fat weights of women who participated in Zumba exercises ( $p>0.05$ ).

The comparison weight of muscle values among Pilates, Step and Zumba groups is shown in table 4. 
Table 4. The comparison weight of muscle values

\begin{tabular}{|c|c|c|c|c|c|c|c|c|c|c|}
\hline \multirow[t]{2}{*}{ Weights of muscle } & \multicolumn{4}{|c|}{ Pre } & \multicolumn{4}{|c|}{ Post } & \multirow[b]{2}{*}{$\mathrm{p}$} & \multirow[b]{2}{*}{$\begin{array}{l}\text { Post } \\
\text { hoc }\end{array}$} \\
\hline & Group & $\mathrm{N}$ & $\mathrm{X} \pm$ Std. & $f$ & $\mathrm{p}$ & $\begin{array}{l}\text { Post } \\
\text { hoc }\end{array}$ & $\mathrm{X} \pm$ Std. & $\mathrm{f}$ & & \\
\hline \multirow[t]{3}{*}{ Arms (kg) } & Pilates & 39 & $4.7 \pm 0.54$ & 1.952 & .151 & None & $4.82 \pm 0.56$ & 2.600 & .083 & None \\
\hline & Step & 10 & $4.33 \pm 0.5$ & & & & $4.43 \pm 0.39$ & & & \\
\hline & Zumba & 11 & $4.5 \pm 0.67$ & & & & $4.52 \pm 0.68$ & & & \\
\hline \multirow[t]{3}{*}{ Legs (kg) } & Pilates & 39 & $14.36 \pm 1.46$ & .841 & .437 & None & $14.45 \pm 1.36$ & .485 & .618 & None \\
\hline & Step & 10 & $13.76 \pm 1.27$ & & & & $14.04 \pm 1.1$ & & & \\
\hline & Zumba & 11 & $14.4 \pm 1.04$ & & & & $14.2 \pm 1.1$ & & & \\
\hline \multirow{3}{*}{$\begin{array}{l}\text { Core abdominal } \\
\text { area }(\mathrm{kg})\end{array}$} & Pilates & 39 & $26.91 \pm 2.92$ & .457 & .635 & None & $27.53 \pm 3.03$ & 1.054 & .355 & None \\
\hline & Step & 10 & $25.99 \pm 2.4$ & & & & $26.28 \pm 2.01$ & & & \\
\hline & Zumba & 11 & $26.49 \pm 2.86$ & & & & $26.53 \pm 2.86$ & & & \\
\hline \multirow[t]{3}{*}{ Total body (kg) } & Pilates & 39 & $45.98 \pm 4.82$ & .342 & .711 & None & $46.8 \pm 4.86$ & 1.061 & .353 & None \\
\hline & Step & 10 & $44.66 \pm 4.2$ & & & & $44.75 \pm 3.41$ & & & \\
\hline & Zumba & 11 & $45.39 \pm 4.5$ & & & & $45.26 \pm 4.55$ & & & \\
\hline
\end{tabular}

Women participating in the exercises; there was no statistically significant difference between the Pilates, Step and Zumba groups in terms of pretest and posttest mean values of arms, legs, core abdominal area and total body muscle weight ( $\mathrm{p}>0.05)$.

The comparison weight of fat values among Pilates, Step and Zumba groups is shown in table 5.

Table 5. The comparison weight of fat values

\begin{tabular}{|c|c|c|c|c|c|c|c|c|c|c|}
\hline \multirow{2}{*}{$\begin{array}{l}\text { Weights of } \\
\text { fat }\end{array}$} & \multicolumn{4}{|c|}{ Pre } & \multicolumn{4}{|c|}{ Post } & \multirow[b]{2}{*}{$\mathrm{p}$} & \multirow[b]{2}{*}{$\begin{array}{l}\text { Post } \\
\text { hoc }\end{array}$} \\
\hline & Group & $\mathrm{N}$ & $\mathrm{X} \pm$ Std. & $f$ & $\mathrm{p}$ & $\begin{array}{l}\text { Post } \\
\text { hoc }\end{array}$ & $\mathrm{X} \pm$ Std. & $f$ & & \\
\hline \multirow[t]{3}{*}{ Arms (kg) } & Pilates & 39 & $3.21 \pm 1.38$ & \multirow[t]{3}{*}{3.200} & \multirow[t]{3}{*}{$.048 *$} & \multirow[t]{3}{*}{$\mathrm{P}>\mathrm{Z}$} & $3.05 \pm 1.37$ & \multirow[t]{3}{*}{4.392} & \multirow[t]{3}{*}{$.017 *$} & $\mathrm{P}>\mathrm{S}$, \\
\hline & Step & 10 & $2.42 \pm 1.04$ & & & & $1.96 \pm 0.87$ & & & $\mathrm{Z}$ \\
\hline & Zumba & 11 & $2.33 \pm 0.61$ & & & & $2.25 \pm 0.57$ & & & \\
\hline \multirow[t]{3}{*}{ Legs (kg) } & Pilates & 39 & $11.6 \pm 2.92$ & \multirow[t]{3}{*}{5.235} & \multirow[t]{3}{*}{$.008^{*}$} & \multirow{3}{*}{$\begin{array}{l}\mathrm{P}>\mathrm{S}, \\
\mathrm{Z}\end{array}$} & $11.32 \pm 2.98$ & \multirow[t]{3}{*}{5.724} & \multirow[t]{3}{*}{$.005 *$} & $\mathrm{P}>\mathrm{S}$, \\
\hline & Step & 10 & $9.2 \pm 2.32$ & & & & $8.48 \pm 2$ & & & $\mathrm{Z}$ \\
\hline & Zumba & 11 & $9.31 \pm 1.89$ & & & & $9.37 \pm 1.75$ & & & \\
\hline \multirow{3}{*}{$\begin{array}{l}\text { Core abdominal } \\
\text { area }(\mathrm{kg})\end{array}$} & Pilates & 39 & $11.38 \pm 3.29$ & \multirow[t]{3}{*}{4.111} & \multirow[t]{3}{*}{$.021 *$} & $\mathrm{P}>\mathrm{S}$, & $10.25 \pm 3.69$ & \multirow[t]{3}{*}{3.552} & \multirow[t]{3}{*}{$.035 *$} & \multirow[t]{3}{*}{$\mathrm{P}>\mathrm{S}$} \\
\hline & Step & 10 & $8.74 \pm 3.33$ & & & $\mathrm{Z}$ & $7.05 \pm 3.19$ & & & \\
\hline & Zumba & 11 & $8.95 \pm 3.13$ & & & & $8.73 \pm 3.13$ & & & \\
\hline \multirow[t]{3}{*}{ Total body (kg) } & Pilates & 39 & $26.21 \pm 7.25$ & \multirow[t]{3}{*}{4.741} & \multirow[t]{3}{*}{$.012 *$} & \multirow{3}{*}{$\begin{array}{l}\mathrm{P}>\mathrm{S}, \\
\mathrm{Z}\end{array}$} & $24.63 \pm 7.46$ & \multirow[t]{3}{*}{5.019} & \multirow[t]{3}{*}{$.010 *$} & \multirow[t]{3}{*}{$\mathrm{P}>\mathrm{S}$} \\
\hline & Step & 10 & $20.36 \pm 6.61$ & & & & $17.49 \pm 6$ & & & \\
\hline & Zumba & 11 & $20.6 \pm 5.44$ & & & & $20.36 \pm 5.16$ & & & \\
\hline
\end{tabular}

*p $<0.05 \mathrm{P}=$ Pilates, $\mathrm{S}=$ Step, $\mathrm{Z}=\mathrm{Zumba}$

Pilates, Step and Zumba women who will participate in the exercises; the pretest means of fat weight in arms, legs, core abdominal area, and total body had a statistically significant difference between the groups $(\mathrm{p}<0.05)$. Women participating in the exercises; there was a statistically significant difference between the Pilates, Step and Zumba groups in terms of posttest mean values of arms, legs, core abdominal area, and total body muscle weight $(\mathrm{p}<0.05)$.

The fat weight in the legs, core abdominal area and total body of the women who will participate in Pilates exercises is statistically higher than the women who will participate in Step and Zumba exercises. Fat of arms weights of the women who will participate in Pilates exercises are significantly higher than the pretest results of women who will only participate in Zumba exercises. The pretest fat weights of the women who will participate in Step and Zumba exercises do not show any statistically significant difference, they have mathematically close values. Women who participated in Pilates exercises had significantly higher fat weights in arms and legs than those who participated in Step and Zumba exercises. Core abdominal area and total body fat weights of the women who participated in Pilates exercises were significantly higher than the posttest results of women who participated in step exercises only. Posttest fat weights of all women participating in Step and Zumba exercises did not show a statistically significant difference, they were mathematically close.

\section{Discussion and Conclusions}

Pilates exercises increase the arm, core abdominal area and total body muscle weights of women positively and this difference is statistically significant. As a result of Pilates exercises, there is a mathematical increase in legs muscle weights. There is a mathematical increase in arm, leg, core abdominal area and total body muscle weights of women participating in Step exercises. It is seen that there is almost no change in arm, leg, core abdominal area and total body muscle weights of women participating in Zumba exercises. 
Pilates and Step exercises cause a significant decrease in the arm, leg, core abdominal area, and total body fat weights in women. On the other hand, Zumba exercises, constitute a mathematical reduction in the arm, core abdominal area, and total body fat weights.

When the groups participating in Pilates, Step and Zumba exercises were evaluated among themselves, there was no difference in terms of arm, leg, core abdominal area and total body muscle weights both in the pre-post tests. Exercises provide an increase in arm, leg, core abdominal area and total body muscle weights, but there is no difference between the groups because this increase occurs in all groups.

When the exercise groups were evaluated among themselves according to the pretest results, the leg, core abdominal area and total body fat weights of Pilates group were higher than those of Step and Zumba groups and only the Zumba group in terms of fat weight in arms. When the exercise groups were evaluated among themselves according to the posttest results, the fat weights of the Pilates group were higher in the arms and legs than in the Step and Zumba groups and in the core abdominal area and total body fat weights only in the Step group. In the Step group, the fat weight reduction in the arms was higher than in the other groups. The core abdominal area and total body fat weights of the Zumba group were also lower than those of the Pilates and Step groups.

In the literature, studies are showing the beneficial effects of Pilates exercises on body weight, body mass index (BMI), body composition and flexibility performance (Aladro-Gonzalvo, Machado-Díaz, Moncada-Jiménez, Hernández-Elizondo, \& Araya-Vargas, 2012; Fourie, et al., 2013). Baştug, et al., (2014) reported that Pilates exercises are one of the most important methods in improving flexibility performance and body composition. Pilates exercises are performed 2 to 3 times a week for 5 to 12 weeks and increase the endurance of the abdominal muscles for both genders (Campos, et al., 2016).

Şavkın \& Aslan, (2017) found that the 8-week Pilates exercise program had positive effects on body composition in sedentary overweight and obese women. In the same study, it was reported that fat percentage, waist, abdomen and hip circumference of women decreased significantly as a result of exercises $(\mathrm{p}<0.05)$. As a result, no significant difference was observed in fat-free body mass ( $p>0.05)$. There is no consensus in the literature as to whether physical activity is important for total body mass loss and improved body composition (Pedersen \& Saltin, 2015). Several studies have shown that physical training leads to a reduction in fat mass and abdominal fat, in contrast to the harmful side effects of very restrictive calorie diets that cause a loss of lean mass (Ross \& Janssen, 1999).

Babayigit Irez, et al., (2014), Step and Aerobic dance among college students to reduce body fat percentage or weight gain programs that are as effective as other sports. Step-aerobic exercises cause a significant decrease in body weight, body mass index, waist area and hip circumference of women (Cicek, et al., 2017). The application of Step-aerobic exercises positively affects the health of women aged 20-35 years (Masliak, 2015).

Zumba exercises were found to improve internal motivation, reduce body weight and body fat, and improve the health of obese women (Krishnan, et al., 2015). It was reported that overweight women with a mean age of $38.9 \pm 9.7$ who had a 12-week Zumba exercise program were positively affected in terms of health (Cugusi, et al., 2016).

CrossFit based high-intensity power training, maximum aerobic fitness and body composition were improved, a decrease in body fat ratio of women and men was detected and positive improvements in $\mathrm{VO}_{2}$ max, body weight, and body composition values were observed. Participation in regular exercises was found to cause significant changes in the waist circumference of obese people and female university students (Stensvold, et al., 2010). As a result of regular participation in an aerobic dance exercise program for 12 weeks, there are positive improvements in body composition and cardiorespiratory system in sedentary adults (Williams \& Morton, 1986).

Current findings suggest that concurrent aerobic dance and resistance training have positive effects on weight loss in women (Suksom, Phanpheng, Soogarun, \& Sapwarobol, 2015). Traditionally moderate walking or running programs have been proposed to improve health-related variables (Ross, 2000; Pedersen \& Saltin, 2015). The effects of walking exercises vary according to gender, age, and body mass index (Mabire, Mani, Liu, Mulligan, \& Baxter, 2017), so these variables should be taken into consideration when planning.

\subsection{Suggestions}

Pilates and Step exercises can be recommended to women who want to reduce their weight on arms, legs, core abdominal area and total body fat lose weight. One-hour Pilates, Step and Zumba exercises for 12 weeks and 3 days a week will positively affect the health of individuals. It will be socially beneficial for women who have a sedentary lifestyle and who are not actively engaged in sports to be guided to such exercises with music and in groups. There is no need for a high budget and specially designed spaces to perform exercises such as Pilates, Step, and Zumba, so everyone will be able to reach easily. It would be beneficial for public health units, schools and social community organizations to direct individuals to such exercise programs. 


\section{References}

Aladro-Gonzalvo, A. R., Machado-Díaz, M., Moncada-Jiménez, J., Hernández-Elizondo, J., \& Araya-Vargas, G. (2012). The effect of Pilates exercises on body composition: A systematic review. Journal of Bodywork and Movement Therapies, 16(1), 109-114. https://doi.org/10.1016/j.jbmt.2011.06.001

Babayiğit Irez, G., Saygın, Ö, Yıldırım, S., \& Ceylan, H. (2014). Aerobic dance or step dance: Which exercise can increase balance, flexibility and muscle strength of university students? Academic Journal of Sports, Health and Medical Sciences, 13(4), 143-151.

Baştuğ, G., Ceylan, H. I., \& Kalfa, S. (2014). Examining the effects of pilates exercise programs on flexibility performance and body composition in women. International Journal of Human Sciences, 11(2), 1274. https://doi.org/10.14687/ijhs.v11i2.3093

Baştuğ, G., Özcan, R., Gültekin, D., \& Günay, Ö. (2016). The Effects Of Cross-Fit, Pilates And Zumba Exercise On Body Composition And Body Image Of Women. International Journal of Sports, Exercise and Training Science, 2(1). https://doi.org/10.18826/ijsets. 25037

Campos, R., Dias, J., Pereira, L., Obara, K., Barreto, M., Silva, M., ... \& Cardoso, J. (2016). Effect of The Pilates Method on Physical Conditioning of Healthy Subjects: A Systematic Review and Meta-Analysis. The Journal of Sports Medicine and Physical Fitness,56(7-8), 864-873. Retrieved from https://www.ncbi.nlm.nih.gov/pubmed/26004043

Cicek, G., Imamoglu, O., Gullu, A., Celik, O., Ozcan, O., Gullu, E., \& Yamaner, F. (2017). The effect of exercises on left ventricular systolic and diastolic heart function in sedentary women: Step-aerobic vs core exercises. Journal of Exercise Science \& Fitness, 15(2), 70-75. https://doi.org/10.1016/j.jesf.2017.07.002

Cugusi, L., Wilson, B., Serpe, R., Medda, A., Deidda, M., Gabba, S., ... \& Mercuro, G. (2016). Cardiovascular effects, body composition, quality of life and pain after a Zumba ${ }^{\circledR}$ fitness program in Italian overweight women. The Journal of Sports Medicine and Physical Fitness, 56(3), 328-335. Retrieved from https://www.ncbi.nlm.nih.gov/pubmed/25693596

Delextrat, A. A., Warner, S., Graham, S., \& Neupert, E. (2016). An 8-week Exercise Intervention Based on Zumba Improves Aerobic Fitness and Psychological Well-Being in Healthy Women. Journal Phys Act Health, 13(2), 131-139. https://doi.org/10.1123/jpah.2014-0535

Fourie, M., Gildenhuys, G., Shaw, I., Shaw, B., Toriola, A., \& Goon, D. (2013). Effects of a Mat Pilates Programme on Body Composition in Elderly Women. West Indian Medical Journal, 62(6). https://doi.org/10.7727/wimj.2012.107

Garcia, P. T., \& Aznar, L. S. (2011). Práctica del método Pilates: cambios en composición corporal y flexibilidad en adultos sanos. Apunts. Medicina de l'Esport, 46(169), 17-22. https://doi.org/10.1016/j.apunts.2010.07.001

Garrick, J. G., \& Requa, R. K. (1988). Aerobic Dance. Sports Medicine, 6(3), 169-179. https://doi.org/10.2165/00007256-198806030-00004

Jakicic, J. M., Clark, K., Coleman, E., Donnelly, J. E., Foreyt, J., Melanson, E., ... \& Volpe, S. L. (2001). Appropriate Intervention Strategies for Weight Loss and Prevention of Weight Regain for Adults. Medicine \& Science in Sports \& Exercise, 33(12), 2145-2156. https://doi.org/10.1097/00005768-200112000-00026

Jebb, S. A., Cole, T. J., Doman, D., Murgatroyd, P. R., \& Prentice, A. M. (2000). Evaluation of the novel Tanita body-fat analyser to measure body composition by comparison with a four-compartment model. British Journal of Nutrition, 83(2), 115-122. https://doi.org/10.1017/s0007114500000155

Krishnan, S., Tokar, T. N., Boylan, M. M., Griffin, K., Feng, D., Mcmurry, L., ... \& Cooper, J. A. (2015). Zumba® Dance Improves Health in Overweight/Obese or Type 2 Diabetic Women. American Journal of Health Behavior, 39(1), 109-120. https://doi.org/10.5993/ajhb.39.1.12

Latey, P. (2001). The Pilates method: History and philosophy. Journal of Bodywork and Movement Therapies, 5(4), 275-282. https://doi.org/10.1054/jbmt.2001.0237

Luettgen, M., Foster, C., Doberstein, S., Mikat, R., \& Porcari, J. (2012). Zumba®: Is the "Fitness-Party" a Good Workout? J Sports Sci Med, 11(2), 357-358. Retrieved from https://www.ncbi.nlm.nih.gov/pmc/articles/PMC3737860/

Mabire, L., Mani, R., Liu, L., Mulligan, H., \& Baxter, D. (2017). The Influence of Age, Sex and Body Mass Index on the Effectiveness of Brisk Walking for Obesity Management in Adults: A Systematic Review and Meta-Analysis. Journal of Physical Activity and Health, 14(5), 389-407. https://doi.org/10.1123/jpah.2016-0064

Manson, J. E., Colditz, G. A., Stampfer, M. J., Willett, W. C., Rosner, B., Monson, R. R., ... \& Hennekens, C. H. (1990). A 
Prospective Study of Obesity and Risk of Coronary Heart Disease in Women. New England Journal of Medicine, 322(13), 882-889. https://doi.org/10.1056/nejm199003293221303

Masliak, I. (2015). Physical health of young and middle age women under influence of step-aerobics exercises. Pedagogics, Psychology, Medical-biological Problems of Physical Training and Sports, 19(10), 45-50. https://doi.org/10.15561/18189172.2015.1007

Mazzarino, M., Kerr, D., Wajswelner, H., \& Morris, M. E. (2015). Pilates Method for Womens Health: Systematic Review of Randomized Controlled Trials. Archives of Physical Medicine and Rehabilitation, 96(12), 2231-2242. https://doi.org/10.1016/j.apmr.2015.04.005

Nunez, C., Gallagher, D., Visser, M., Pi-Sunyer, F. X., Wang, Z., \& Heymsfield, S. B. (1997). Bioimpedance analysis: Evaluation of leg-to-leg system based on pressure contact foot-pad electrodes. Medicine \& Science in Sports \& Exercise, 29(4), 524-531. https://doi.org/10.1097/00005768-199704000-00015

Pedersen, B. K., \& Saltin, B. (2015). Exercise as medicine - evidence for prescribing exercise as therapy in 26 different chronic diseases. Scandinavian Journal of Medicine \& Science in Sports, 25, 1-72. https://doi.org/10.1111/sms.12581

Professional Scales. (n.d.). Retrieved July 3, 2019, from https://www.tanita.com/en/

Ross, R. (2000). Reduction in Obesity and Related Comorbid Conditions after Diet-Induced Weight Loss or Exercise-Induced Weight Loss in Men. Annals of Internal Medicine, 133(2), 92. https://doi.org/10.7326/0003-4819-133-2-200007180-00008

Ross, R., \& Janssen, I. (1999). Is abdominal fat preferentially reduced in response to exercise-induced weight loss? Medicine \& Science in Sports \& Exercise, 31(Supplement 1). https://doi.org/10.1097/00005768-199911001-00014

Şavkın, R., \& Aslan, U. B. (2017). The effect of Pilates exercise on body composition in sedentary overweight and obese women. The Journal of Sports Medicine and Physical Fitness, 57(11), 1464-1470. https://doi.org/10.23736/S0022-4707.16.06465-3

Scharff-Olson, M., Williford, H. N., Blessing, D. L., \& Brown, J. A. (1996). The Physiological Effects of Bench/Step Exercise. Sports Medicine, 21(3), 164-175. https://doi.org/10.2165/00007256-199621030-00002

Singh, T. N., \& Singh, S. V. K. (2014). Effect of twelve weeks exercise program with Pilates on body composition among school boys of Manipur. International Educational E-Journal, Quarterly, 3(1), 214-220. https://www.oiirj.org/ejournal/july-aug-sept2014/02.pdf

Stensvold, D., Tjønna, A. E., Skaug, E., Aspenes, S., Stølen, T., Wisløff, U., \& Slørdahl, S. A. (2010). Strength training versus aerobic interval training to modify risk factors of metabolic syndrome. Journal of Applied Physiology, 108(4), 804-810. https://doi.org/10.1152/japplphysiol.00996.2009

Suksom, D., Phanpheng, Y., Soogarun, S., \& Sapwarobol, S. (2015). Step aerobic combined with resistance training improves cutaneous microvascular reactivity in overweight women. The Journal of Sports Medicine and Physical Fitness,55(12), 1547-1554. Retrieved from https://www.ncbi.nlm.nih.gov/pubmed/25303169

Terry, R. B., Stefanick, M. L., Haskell, W. L., \& Wood, P. D. (1991). Contributions of regional adipose tissue depots to plasma lipoprotein concentrations in overweight men and women: Possible protective effects of thigh fat. Metabolism, 40(7), 733-740. https://doi.org/10.1016/0026-0495(91)90093-c

Tolnai, N., Szabó, Z., Köteles, F., \& Szabo, A. (2016). Physical and psychological benefits of once-a-week Pilates exercises in young sedentary women: A 10-week longitudinal study. Physiology \& Behavior, 163, 211-218. https://doi.org/10.1016/j.physbeh.2016.05.025

Williams, L. D., \& Morton, A. R. (1986). Changes in selected cardiorespiratory responses to exercise and in body composition following a 12-week aerobic dance programme. Journal of Sports Sciences, 4(3), 189-199. https://doi.org/10.1080/02640418608732118

Williford, H. N., Scharff-Olson, M., \& Blessing, D. L. (1989). The Physiological Effects of Aerobic Dance. Sports Medicine, 8(6), 335-345. https://doi.org/10.2165/00007256-198908060-00003

\section{Copyrights}

Copyright for this article is retained by the author(s), with first publication rights granted to the journal.

This is an open-access article distributed under the terms and conditions of the Creative Commons Attribution license which permits unrestricted use, distribution, and reproduction in any medium, provided the original work is properly cited. 